\title{
Enhancement in the Productivity and Economics of Pearl Millet and Mung Bean Inter Cropping System through Different Sowing Geometries in Pothwar
}

\section{Safdar Ali'*, Muhammad Umar ${ }^{1}$, Bashir Ahmad Khan ${ }^{2}$, Ijaz Ahmed $^{3}$, Amir Manzoor ${ }^{1}$, Muhammad Saqib Riaz $^{1}$, Muhammad Irfan Arif ${ }^{1}$ and Asif Nawaz ${ }^{1}$}

${ }^{1}$ Department of Agronomy, PMAS-Arid Agriculture University Rawalpindi, Pakistan; ${ }^{2}$ Department of Economics, PMAS-Arid Agriculture University Rawalpindi, Pakistan; ${ }^{3}$ Ecotoxicology Research Institute, National Agricultural Research Centre Islamabad, Pakistan.

Abstract | Generally, there is subsistence kind of farming in Pothwar Region of Pakistan. The per unit area income of farmers is very low and the soils of this region are very poor. Mostly mono-cropping system is prevailing here. So, the pearl millet and mung bean were selected as test crops to evaluate the intercropping system in this region for the ultimate improvement of the net profitability of the farmers per unit area simultaneously not compromising with the food security and soil health. Different line spacing's (inter and intra strip) i.e., 30, 60 and $90 \mathrm{~cm}$ were maintained along with different number of lines of pearl millet and mung bean i.e., 1, 2 and 3 in the form of strips for comparison. The results showed that intercropping significantly reduced density and dry biomass of weeds per unit area. Moreover, the biological yield, grain yield and the harvesting index of pearl millet and mung bean were also affected significantly under different sowing geometries. Both crops growth and yield was increased in the narrow row spacing as compared to wider row spacing, whereas, weed density and biomass was decreased in narrow spacing that may be due to less availability of space and more intra and inter specific competition. Maximum land equivalent ratio (1.8) was found under the plot where alternate strips of three lines of both crops were grown at $30 \mathrm{~cm}$ intra and inter strip distance and it was followed by (1.7) in the treatment where single lines of both crops were grown alternately at $30 \mathrm{~cm}$ distance. Similarly, the net income of intercropped plots having three lines of both crops grown alternately in the form of strips at $30 \mathrm{~cm}$ intra and inter strip spacing, was $116 \%$ higher than sole mung bean crop and 56\% higher than sole pearl millet crop. Maximum weeds $\left(106.4 \mathrm{~m}^{-2}\right)$ were observed in single alternate lines of both crops grown at $90 \mathrm{~cm}$ intra and inter strip distance whereas minimum $\left(75.2 \mathrm{~m}^{-}\right.$ $\left.{ }^{2}\right)$ in triple lines of both crops grown alternately in the form of strips having $30 \mathrm{~cm}$ intra and inter strip distance. Therefore, intercropping of mung bean and pearl millet in the form of strips of three lines having $30 \mathrm{~cm}$ intra and inter strip distance is recommended to the farming community of Pothwar Region of Pakistan for taking maximum net returns per unit area per unit time through inter cropping in kharif season.

Received | September 30, 2019; Accepted | November 04, 2021; Published | January 12, 2022

*Correspondence | Safdar Ali, Department of Agronomy, PMAS-Arid Agriculture University Rawalpindi, Pakistan; Email: safdaraliarid@ yahoo.com

Citation | Ali, S., M. Umar, B.A. Khan, I. Ahmed, A. Manzoor, M.S. Riaz, M.I. Arif and A. Nawaz. 2021. Enhancement in the productivity and economics of pearl millet and mung bean inter cropping system through different sowing geometries in Pothwar. Pakistan Journal of Agricultural Research, 34(4): 889-896.

DOI | https://dx.doi.org/10.17582/journal.pjar/2021/34.4.889.896

Keywords | Weeds, Millet, Mung bean, Inter-cropping, Productivity, Profitability, Row spacing 
Introduction

$\mathrm{P}_{\mathrm{P}, \mathrm{s}}^{\mathrm{e}}$ earl millet (Pennisetum glaucum L.) is $6^{\text {th }}$ most important cereal cultivated in all over the world and fifth of Pakistan. It was introduced from central tropic Africa and later on spread in Western state from Wild West African grass. Now it has been extended into sub-tropic semi-arid regions of Asia and Africa. Pearl millet is chiefly grown for consumption of humans serving as standard food in some countries which are poor and regions of continent in Africa. The grain can be used as dough gruel and as grainlike flour (Brunken et al., 1977; Coutin and Harris, 1969). Millet is a drought tolerant most important crop that can be grown under the harsh environmental conditions where other cereals may not be successful to produce grains. These regions are described by abnormal circulation of annual rainfall, high mean temperature and reduced soil fertility. It is cultivated on about 0.548 million hectares and produce 0.201 million tones yield and in Pakistan $631 \mathrm{~kg} / \mathrm{ha}$ is average yield (NARC, 2014). The crop gives very low grain yield. Use of traditional low yielding cultivars, less plant population, low level of usage of fertilizers, inefficient weed control methods and no water conservation are major reasons of lower crop productions (NARC, 2014). Carbohydrates are the major component of grains i.e., $70 \%$. The starch is made up of about one-third amylose and two-third amylopectin. Protein value ranges 9 to $21 \%$ with $16 \%$ mean. Biological and edible value of protein has been calculated that is $89 \%$ and $83 \%$, respectively. Protein competence ratio 1.43 has been found which is more efficient than wheat (1.2). Pearl millet contains 5\% fat and vitamin values comparatively lower than that of maize. Even though the vitamin A level is best, the value of carotene in millet is higher. It is more beneficial than wheat, rice, maize and sorghum (Agte et al., 1999; Muthamilarasan et al., 2016). Several traditional beverages and foods are made from pearl millet, i.e., dough's, gruels, porridges, flatbreads, beer and beverages which are nonalcoholic. It can grow even on the porous soil in the regions where rainfall is very low and on soils that are saline in the hottest climate. This crop plays a double role such as grain of millet is used for human food utilization and the hay as fodder for the cattle. Pakistan stands $12^{\text {th }}$ in the production of millet, the India is on $1^{\text {st }}$, on $2^{\text {nd }}$ is Niger and China is on $3^{\text {rd }}$ (FAOSTAT, 2016). Within the other compatible crops to the pearl millet Mung bean [ $\mathrm{Vi}-$ gna radiata (L.)] is one for intercropping from them.
Mung Bean is an annual leguminous crop of dry and warm locality and identified as one of the most drought tolerant crop in arid regions. Deep-rooted mung beans penetrate deep into the soil and have drought-resisting ability which can survive and thrive for a long time in the open field having rapid dehydration of soil moisture and extremely high atmospheric temperature. The crop has become an important part of all planting and farming systems of semi-arid areas because of its adjustment nature. In Southeast Asia Mung Bean [Vigna radiata (L.)] is most significant bean crop. Edible protein is (24\%) which is higher in this. Mung bean is used in diets which are cereal-based (Khattak et al., 2003). It possesses iron (7.3mg), folate (594mg), vitamin A (94mg), calcium (124mg) and zinc $(3 \mathrm{mg})$ per $100 \mathrm{~g}$ of dry seed. It is used in different food products and in divided form (Dahl) (Rasul et al., 2012). Being less demanding inputs, little period, restorative crop and high value crop, mung bean is familiar in crop rotations (Achakzai et al., 2012). Mung bean is a legume crop where nitrogen is fixed by legumes to increase soil fertility and requires relatively a smaller number of irrigations than other crops (Khan et al., 2008). Pulses in addition to being a dietary ingredient they also provide relief to cropping systems. They fit suitably in crop rotation, restore soil fertility by fixing atmospheric nitrogen and have capacity to extract the soil moisture through deep root system. They are also known as the main source of vegetarian protein. They also constitute as the main source of vegetable protein. Mung bean as a legume crop is nitrogen fixing crop and this is done by the symbiotic nitrogen fixing process. It is suitable for the intercropping system as a short-term crop i.e., Pearl millet + mung bean intercropping system (Ghilotia et al., 2015).

In the food-production system of struggling countries inter cropping has a significant role where minor farms and labor- severe operations dominate, stability of yield in several seasons and increase in the alternative crops yield is a common advantage of intercropping. Inter-cropping has been modified as a system of future constructive of crop production in regions of arid zone. Inter-cropping is a beneficial system in light of increased demands of households, good and a source of family labor employment (Ghilotia et al., 2015). This approach is an important payment system and huge value for production of crop under rain fed condition (Dhoble et al., 1990). To rise the intensity of cropping and per unit area production, inputs and 
time by two or more component crops growing in suitable geometry it is one of the most recognized cropping systems. Cereals inter-cropping with legumes fulfils the 3F's that are Food for human, Feed for animals and Fertility of soil. Intercropping of pearl millet and mung bean enhances the soil health as mung bean is leguminous crop that fixes nitrogen in the soil.

Weeds are the strongest competitors with the crops for water, nutrients, sunlight and space. Weeds are the plants that grow by their self. The growth span of weeds is much shorter than that of crops and here they compete with crops for the necessities a plant needs to grow. Weeds provide shelter to pests and diseases. Weeds are the biggest risk for agriculture and ecosystems, and it is very difficult to control them completely. Removal of weeds by hands is relatively costly and takes a lot of time and labor. Weeds are the main reducing factor for crops yields (Avery, 1997). It is very important to have the accurate narrative for controlling the weed growth.

The goal of this study was to determine the effect of intercropping system on net profitability and weeds dynamics under different sowing geometries.

\section{Materials and Methods}

A field experiment was laid out for determining effect of inter-cropping of Pearl Millet and Mung Bean through different sowing geometries on weed population dynamics, productivity of companion crops and net profitability of farming community per unit area per unit time. The experiment was conducted at University Research Farm, Chakwal Road, Rawalpindi of Pir Mehr Ali Shah Arid Agriculture University Rawalpindi during summer season of 2018 having the soil sandy loam. The experiment was conducted in (RCBD) design having three replications. The net plot size of each treatment was $27 \mathrm{~m}^{2}$ having $5.4 \mathrm{~m}$ $\times 5 \mathrm{~m}$ dimensions. The gross plot size was $1526.8 \mathrm{~m}^{2}$ having $22 \mathrm{~m}$ width and $69.4 \mathrm{~m}$ length including borders and paths. Under intercropped plots the seed rate was reduced by $1 / 3^{\text {rd }}$ of the recommended seed rate for both crops. The whole recommended seed rate of pearl millet and mung bean was used for sole plots @ $15 \mathrm{~kg} / \mathrm{ha}$ and $25 \mathrm{~kg} / \mathrm{ha}$, respectively. NM-11 and Super-1 were the test cultivars of Mung bean and Pearl Millet, respectively. Seeds of both crops were obtained from National Agricultural Research Center Islamabad. Sowing date of the experiment was $23^{\text {rd }}$
July 2018. Nitrogen and Phosphorus was applied @ $60: 60 \mathrm{~kg} / \mathrm{ha}$ and $20: 60 \mathrm{~kg} / \mathrm{h}$ to pearl millet and mung bean sole plots respectively and @ 40:60 kg/ha to the intercropped plots. Weeding was done after 30 days of sowing. Harvesting dates of Mung bean and Pearl millet were 20 October 2018 and 08 November 2018, respectively. Data for parameters of yield of both crops were noted applying standard protocols. The experimental soil was tested for soil characteristics which are mentioned in Table 2. The meteorological data was collected from the nearest Meteorological Observatory installed at University Research Farm that is presented in Figure 1. Both crops were grown through different sowing geometries that are following.

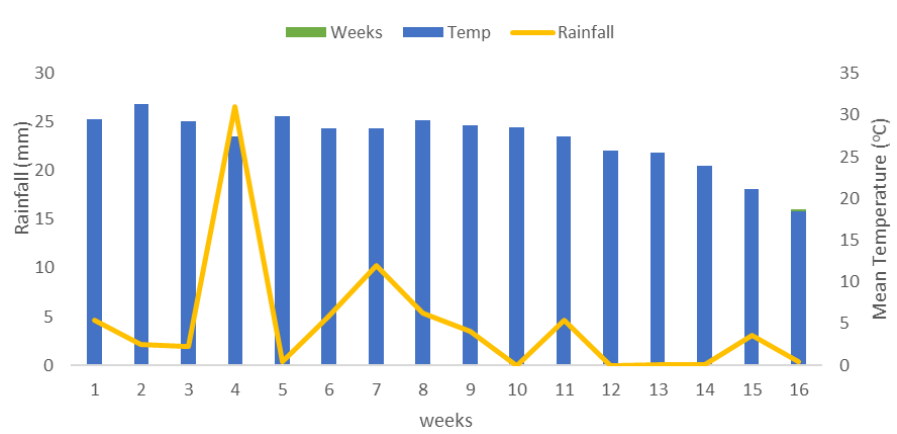

Figure 1: Temperature and rainfall data during experimental season.

Treatments

There were 11 integrated treatments of this experiment as per mentioned in (Table 1 );

\section{Results and Discussion}

Temperature and rainfall data during experimental period

The data about mean rainfall (bars) and daily temperature (solid line) throughout whole experimental period has been displayed in (Figure 1). The solid line shows that $\left(29.49^{\circ} \mathrm{C}\right)$ mean daily temperature was noted at the time of land preparation. It was increased up to $31.30{ }^{\circ} \mathrm{C}$ in $2^{\text {nd }}$ week of experimental period while the lowest temperature was recorded in $16^{\text {th }}$ week, i.e. $18{ }^{\circ} \mathrm{C}$. Maximum rainfall of whole growing season was recorded $26.54 \mathrm{~mm}$ in $4^{\text {th }}$ week while no rainfall was recorded in $12^{\text {th }}, 13^{\text {th }}$ and $14^{\text {th }}$ week.

\section{Properties of soil of experimental area}

Experiment was carried out at University Research Farm, Chakwal Road Rawalpindi, situated at 32.9303 $\mathrm{N}$ latitude, longitudinally $72.8556^{\circ} \mathrm{E}$, and with 2500 feet altitude from level of sea, in 2018 during kharif season. The soil used was of loamy series containing 
E.C. 0.80 and 0.81 dscm-1, PH 7.39 and 7.46 phosphorous available 4.59 and $2.91 \mathrm{mg} / \mathrm{kg}$, potassium available 100 and $80 \mathrm{mg} / \mathrm{kg}$, organic matter 0.45 and $0.30 \%$ for $0-15 \mathrm{~cm}$ and $15-30 \mathrm{~cm}$ soil depths respectively (Table 2).

Table 1: Treatments of the experiment.

\section{Treatment Detail}

No.

T1 Alternate lines of pearl millet and mung bean at $90 \mathrm{~cm}$ line to line distances

T2 Alternate lines of pearl millet and mung bean at $60 \mathrm{~cm}$ line to line distances

T3 Alternate lines of pearl millet and mung bean at $30 \mathrm{~cm}$ line to line distances

T4 Alternate strips of two lines of each crop having $30 \mathrm{~cm}$ intra and $90 \mathrm{~cm}$ inter strip distances

T5 Alternate strips of two lines of each crop having $30 \mathrm{~cm}$ intra and $60 \mathrm{~cm}$ inter strip distances

T6 Alternate strips of two lines of each crop having $30 \mathrm{~cm}$ intra and $30 \mathrm{~cm}$ inter strip distances

T7 Alternate strips of three lines of each crop having $30 \mathrm{~cm}$ intra and $90 \mathrm{~cm}$ inter strip distances

T8 Alternate strips of three lines of each crop having $30 \mathrm{~cm}$ intra and $60 \mathrm{~cm}$ inter strip distances

T9 Alternate strips of three lines of each crop having $30 \mathrm{~cm}$ intra and $30 \mathrm{~cm}$ inter strip distances

T10 Mung bean only at $30 \mathrm{~cm}$ line to line distance

T11 Pearl millet only at $60 \mathrm{~cm}$ line to line distance

Table 2: Physio-chemical properties of experimental soil.

\section{Soil Characteristics}

$\begin{array}{lll}\text { Soil Depth }(\mathrm{cm}) & 0-15 \mathrm{~cm} & 15-30 \mathrm{~cm} \\ \text { PH } & 7.39 & 7.46 \\ \text { Electrical Conductivity }\left(\mathrm{dSm}^{-1}\right) & 0.80 & 0.81 \\ \text { Available Phosphorus }\left(\mathrm{mg} \mathrm{kg}^{-1}\right) & 4.59 & 2.91 \\ \text { Extractable Potassium }\left(\mathrm{mg} \mathrm{kg}^{-1}\right) & 100 & 80 \\ \text { Organic Matter (\%) } & 0.45 & 0.30 \\ \text { Texture } & \text { Loamy } & \text { Loamy }\end{array}$

\section{Weeds density (No. $\left.\mathrm{m}^{-2}\right)$}

Data regarding weeds density as influenced by pearl millet and mung bean intercropping at different row spacing has been presented in Table 3. Among all treatments a significant difference was observed. Maximum number of weeds was recorded in T1 (106.4) where single lines of both crops were grown alternately at a distance of $90 \mathrm{~cm}$, it was different significantly from all other treatments statistically and minimum weed density was recorded in T9 (75.2) where three lines were grown of both crops alternately in strips form having $30 \mathrm{~cm}$ intra and inter strip distances. It was observed that the narrower the inter-row spacing less was the weed density. In low spacing non availability of enough space to weeds could be a reason that resulted into low density of weeds. Inter-cropping treatments displayed fewer densities of weeds than in sole treatments. Same results have been reported by Arunvenkatesh et al. (2017) and they concluded that density of weed and the weed dry matter was minimum at a $30 \mathrm{~cm}$ row space as compared to 60 $\mathrm{cm}$ which was due to lesser space available for weeds to grow.

Table 3: Weeds density and dry biomass as influenced by pearl millet and mung bean intercropping.

$\begin{array}{lll}\begin{array}{l}\text { Treatments/ } \\ \text { Parameters }\end{array} & \begin{array}{l}\text { Weeds density } \\ \text { (No. m-2) }\end{array} & \begin{array}{l}\text { Weeds dry weight }(\mathbf{g} \\ \mathbf{m}-2)\end{array} \\ \text { T1 } & 106.4^{* *} \mathrm{a} & 415.96^{* *} \mathrm{a} \\ \text { T2 } & 95.2 \mathrm{c} & 361.1 \mathrm{bc} \\ \text { T3 } & 85.9 \mathrm{f} & 322.0 \mathrm{c}-\mathrm{f} \\ \text { T4 } & 103.3 \mathrm{~b} & 376.2 \mathrm{ab} \\ \text { T5 } & 92.8 \mathrm{~cd} & 353.2 \mathrm{~b}-\mathrm{d} \\ \text { T6 } & 81.7 \mathrm{~g} & 315.8 \mathrm{~d}-\mathrm{g} \\ \text { T7 } & 90.6 \mathrm{de} & 349.2 \mathrm{~b}-\mathrm{d} \\ \text { T8 } & 88.4 \mathrm{e} & 341.6 \mathrm{~b}-\mathrm{e} \\ \text { T9 } & 75.2 \mathrm{~h} & 275.6 \mathrm{~g} \\ \text { T10 } & 81.3 \mathrm{~g} & 302.0 \mathrm{e}-\mathrm{g} \\ \text { T11 } & 79.3 \mathrm{~g} & 289.5 \mathrm{fg}\end{array}$

${ }^{* * *}=$ Highly significant; All treatments have been defined in Table 1 for the ease of readers

\section{Weeds dry weight $\left(\mathrm{gm}^{-2}\right)$}

The data of dry weight of weeds as influenced by pearl millet and mung bean intercropping at different row spacing is displayed in Table 3. In the dry weight of the weeds a significant difference was observed. The higher weeds dry weight was measured in T1 (415.9) where single lines of both crops were grown alternately at a distance of $90 \mathrm{~cm}$ and the minimum weeds dry weight was recorded in T9 (275.6) where three lines were grown of both crops alternately in the strips form having $30 \mathrm{~cm}$ intra and inter strip distances. It was noted that the narrow rows reduced density of weed and dry weight/dry matter of weeds because in narrow row spacing it did not get enough space to grow so the weed growth was suppressed and resulted into so low dry matter. Similar work has been done by Arunvenkatesh et al. (2017) and they concluded that dry weight was higher where the weeds were more and row spacing was wider. 
Table 4: Grain yield, biological yield and harvest Index of pearl millet and mung bean as influenced by different treatments.

$\begin{array}{lllllll}\text { Treatments } & \begin{array}{l}\text { Crops } \\ \text { Pearl millet } \\ \text { Grain Yield } \\ \left(\mathbf{t ~ h a}^{-1}\right)\end{array} & \begin{array}{l}\text { Biological Yield } \\ (\mathbf{t ~ h a})^{-1}\end{array} & \begin{array}{l}\text { Harvest Index } \\ (\%)\end{array} & \begin{array}{l}\text { Mung bean } \\ \text { Grain Yield } \\ \left(\mathbf{t ~ h a}^{-1}\right)\end{array} & \begin{array}{l}\text { Biological Yield } \\ \left(\mathbf{t ~ h a}^{-1}\right)\end{array} & \begin{array}{c}\text { Harvest Index } \\ (\%)\end{array} \\ \text { T1 } & 1.157^{*} \mathrm{c} & 6.30^{* *} \mathrm{c} & 18.37 \mathrm{NS} & 0.190^{* *} \mathrm{f} & 0.760^{*} \mathrm{~d} & \begin{array}{l}25^{*} \mathrm{c} \\ \text { T2 }\end{array} \\ 1.271 \mathrm{bc} & 7.76 \mathrm{bc} & 16.38 & 0.241 \mathrm{ef} & 0.916 \mathrm{~cd} & 26.31 \mathrm{bc} \\ \text { T3 } & 1.41 \mathrm{a}-\mathrm{c} & 8.43 \mathrm{~b} & 16.73 & 0.410 \mathrm{bc} & 1.186 \mathrm{ab} & 34.57 \mathrm{a}-\mathrm{c} \\ \text { T4 } & 1.270 \mathrm{bc} & 7.56 \mathrm{bc} & 16.80 & 0.237 \mathrm{ef} & 0.892 \mathrm{~cd} & 26.57 \mathrm{bc} \\ \text { T5 } & 1.272 \mathrm{bc} & 8.13 \mathrm{~b} & 15.65 & 0.261 \mathrm{~d}-\mathrm{f} & 0.971 \mathrm{~b}-\mathrm{d} & 26.88 \mathrm{bc} \\ \text { T6 } & 1.47 \mathrm{ab} & 8.56 \mathrm{~b} & 17.17 & 0.423 \mathrm{bc} & 1.127 \mathrm{a}-\mathrm{c} & 37.53 \mathrm{ab} \\ \text { T7 } & 1.29 \mathrm{a}-\mathrm{c} & 8.16 \mathrm{~b} & 15.81 & 0.28 \mathrm{de} & 1.127 \mathrm{a}-\mathrm{c} & 24.84 \mathrm{c} \\ \text { T8 } & 1.36 \mathrm{a}-\mathrm{c} & 8.30 \mathrm{~b} & 16.39 & 0.336 \mathrm{~cd} & 1.127 \mathrm{a}-\mathrm{c} & 29.81 \mathrm{a}-\mathrm{c} \\ \text { T9 } & 1.54 \mathrm{a} & 8.93 \mathrm{~b} & 17.25 & 0.433 \mathrm{~b} & 1.127 \mathrm{a}-\mathrm{c} & 38.42 \mathrm{a} \\ \text { T10 } & - & - & - & 0.564 \mathrm{a} & 1.373 \mathrm{a} & 41.08 \mathrm{a} \\ \text { T11 } & 1.56 \mathrm{a} & 10.70 \mathrm{a} & 14.58 & - & - & -\end{array}$

Where ${ }^{* *}=$ Highly Significant; ${ }^{*}=$ Significant; All treatments have been defined in Table 1 for the ease of readers

\section{Grain yield $\left(t h a^{-1}\right)$ of pearl millet}

Data regarding pearl millet grain yield influenced by pearl millet and mung bean inter-cropping at different row spacing has been shown in Table 4. Among all treatments a significant difference was observed. The higher pearl millet grain yield was measured in T10 (1.56) where sole pearl millet was grown at the recommended row to row distance i.e., $60 \mathrm{~cm}$ and the lowest grain yield was recorded in T1 (1.15) where single lines of both crops were grown alternately at a distance of $90 \mathrm{~cm}$. The justification of lower value of grain yield in inter-cropping may be by the reason of severe competition with weeds and resources for crop which made the crop plants inefficient to absorb nutrients and moisture. Similar results were found by Ram and Meena (2014) where they noted that sole pearl millet grain yield was recorded maximum in the sole pearl millet as compared to intercropping treatments. Less nutrients uptake and poor growth with inter-cropping might have less partitioned assimilates to several metabolic sinks and produced less photosynthates that resulted poor development in components of yield.

\section{Grain yield ( $t$ ba $\left.a^{-1}\right)$ of Mung Bean}

The data related to mung bean grain yield of as influenced by the mung bean and pearl millet inter-cropping at different row spacing has been presented in Table 4. Among all treatments a significant difference was noted. The highest grain yield was recorded in
T10 (0.564) where sole mung bean was grown at the recommended row to row distance i.e., $30 \mathrm{~cm}$ and the lowest grain yield of mung bean was recorded in T1 (0.1901) where single lines of both crops were grown alternately at a distance of $90 \mathrm{~cm}$. The reason behind the lower value of grain yield may be due to lower fewer branches/plant' fewer number of seeds/plant and plant population, and $\mathrm{a}$ in the inter-cropping as compared with the sole crop of mung bean. Same findings have been studied by (Khan et al., 2012). They mentioned that reason for losses in yield due to reason of inter-specific competition between pearl millet and mung bean for above and below ground factors of growth i.e., nutrient, soil moisture, solar radiation and space.

\section{Biological Yield $\left(t h a^{-1}\right)$ of Pearl Millet}

The data regarding pearl millet biological yield as influenced by pearl millet and mung bean inter-cropping at different row spacing is presented in Table 4. The maximum biological yield of pearl millet was measured in T10 (10.70) where sole pearl millet was grown at the recommended row to row distance i.e., $60 \mathrm{~cm}$ and the lowest grain yield was measured in $\mathrm{T} 1$ (6.3) where single lines of both crops were grown alternately at a distance of $90 \mathrm{~cm}$. The reason behind the lower biological yield in intercropping may be due to increased competition and more plant population. These results were similar to the findings of Ram and Meena (2014) where they assumed that grain 
yield of sole pearl millet was recorded maximum in the sole pearl millet rather than of intercropping treatments.

\section{Biological Yield $\left(t h a^{-1}\right)$ of Mung Bean}

The data related to mung bean biological yield as influenced by pearl millet and mung bean intercropping at different row spacing is shown in Table 4. Among all the treatments a significant difference was noted. The highest biological yield of mung bean was recorded in T10 (1.373) where sole mung bean was grown at the recommended row to row distance i.e. $30 \mathrm{~cm}$ whereas, the lowest biological yield of mung bean was recorded in T1 (0.760) where single lines of both crops were grown alternately at a distance of $90 \mathrm{~cm}$. The rationale of the lowest value of biological yield may be by the reason of shading effect of pearl millet where maximum solar radiation was not intercepted by the mung bean crop. These findings are same as to the work of (Khan et al., 2012). They assumed that it might be due to high competition between inter-crops for natural resources like sunlight, space, plant nutrient and soil moisture responsible for high rate of photosynthesis responsible for decrease in biological yield.

\section{Harvest Index (\%) of Pearl Millet}

Data related to Pearl Millet harvest index influenced by pearl millet and mung bean intercropping at different row spacing is presented in Table 4. The highest harvest index was calculated in T1 (18.37) where single lines of both crops were grown alternately at a distance of $90 \mathrm{~cm}$ and the lowest index value was measured in T10 (14.58) where pearl millet was grown at the recommended row to row distance i.e., $60 \mathrm{~cm}$.

\section{Harvest Index (\%) of Mung Bean}

Data related to Mung Bean harvest index influenced by pearl millet and mung bean intercropping at different row spacing is presented in Table 4. Among all the treatments a significant difference was observed. The higher harvest index was calculated in T10 (41.08) where sole mung bean was grown at the recommended row to row distance i.e., $30 \mathrm{~cm}$ and the lowest index value was measured in T7 (24.84) where three lines were grown of both crops alternately in the strips form having $30 \mathrm{~cm}$ intra and $90 \mathrm{~cm}$ inter strip distances. It was observed that harvest index was lower in intercropping treatments as compared to the treatment where sole mung bean was grown at $30 \mathrm{~cm}$ row to row distance / line spacing.

\section{Economic Analysis}

\section{Land Equivalent ratio as affected by intercropping:}

Data regarding Land Equivalent Ratio has been showed in Table 5. The higher Land Equivalent $\mathrm{Ra}^{-}$ tio was noted in T9 (1.8) where three lines of both crops were grown alternately in the strips form having $30 \mathrm{~cm}$ intra and inter strip distances. The minimum Land Equivalent Ratio was measured in T1 (1.1) where single lines were grown of both crops alternately at a distance of $90 \mathrm{~cm}$. For LER, if the value is higher than 1.00, it means that there is an inter-cropping yield advantage and inter specific facilitation is greater than competition. If the value of LER is lower than 1.00 it is considered to be of no advantage. In this experiment inter-cropping treatments noted more than 1.00 LER value as related to the sole crop, which showed higher biological efficiency of the inter-cropping treatments. Same results have been showed by Yadav et al. (2015) where he did intercropping of legume in pearl millet and found that intercropping was most profitable as related to sole cropping. This was due to the reason of extra obtained yield from inter-crop and forms combination higher advantageous over the sole crop.

Table 5: Economic Analysis as influenced by pearl millet and mung bean intercropping system.

$\begin{array}{llll}\begin{array}{l}\text { Treatments/ } \\ \text { Parameters }\end{array} & \text { LER } & \begin{array}{l}\text { Benefit Cost } \\ \text { Ratio }\end{array} & \begin{array}{l}\text { Net return (Rs. } \\ \text { ha }^{-1} \text { ) }\end{array} \\ \text { T1 } & 1.1 & 2.3 & 51677.00 \\ \text { T2 } & 1.3 & 2.6 & 64693.70 \\ \text { T3 } & 1.7 & 3.3 & 93649.30 \\ \text { T4 } & 1.3 & 2.6 & 64203.00 \\ \text { T5 } & 1.3 & 2.7 & 67128.90 \\ \text { T6 } & 1.7 & 3.4 & 98462.20 \\ \text { T7 } & 1.4 & 2.8 & 71254.80 \\ \text { T8 } & 1.5 & 3 & 81488.10 \\ \text { T9 } & 1.8 & 3.6 & 104258.50 \\ \text { T10 } & 1 & 3.5 & 48392.20 \\ \text { T11 } & 1 & 3.5 & 66833.90\end{array}$

All treatments have been defined in Table 1 for the ease of readers.

Benefit Cost Ratio (B/C) as affected by intercropping: The data about the Benefit-Cost Ratio has been showed in Table 5. It was observed that highest Benefit Cost Ratio was measured in T9 (3.6) where three lines were grown both crops alternately in the strips form having $30 \mathrm{~cm}$ intra and inter strip distances and lowest in T1 (2.3) where single lines of both crops 
were grown alternately at a distance of $90 \mathrm{~cm}$. From the Table 4 it is obvious that T9 where three lines were grown both crops alternately in the strips form having $30 \mathrm{~cm}$ intra and inter strip distances was highly profitable as related to all other intercropping treatments and sole pearl millet and sole mung bean treatments. Same results have been studied by Sharma et al. (2009) who wroked on the economics and productivity of pearl millet with legumes inter-cropping under different row proportions and found that highest B: C ratio was observed in intercropping treatments as compare to sole treatments.

\section{Net return (Rs. ha- $\left.{ }^{-1}\right)$ as affected by intercropping:}

Data regarding the net return of intercropping of pearl millet and mung bean is presented in Table 5 . It was noted by the data that maximum net return was obtained from T9 (Rs. $104258.5 \mathrm{ha}^{-1}$ ) where three lines were grown both crops alternately in the strips form having $30 \mathrm{~cm}$ intra and inter strip distances. The net income of intercropped plots in T9 where the triple lines were grown both crops alternately in the strips form at $30 \mathrm{~cm}$ intra and inter strip spacing was $116 \%$ higher than sole mung bean crop and it was $56 \%$ higher than sole pearl millet crop. The results were similar to the work of Kumar and Kumar (2018) who showed the inter-cropping treatment of the pearl millet and mung bean $(2: 1)$ gave the highest net return as related to all other inter-cropping and sole treatments. Combined yield of mung bean and pearl millet gave highest gross income and also resulted into highest net return.

\section{Conclusions and Recommendations}

The results showed that intercropping significantly reduced weed density and dry biomass of weeds per unit area. Moreover, the biological yield, grain yield, and harvest index of pearl millet and mung bean were also affected significantly under different sowing geometries. Growth and yield of both crops was increased in the narrow row spacing as compared to wider row spacing; whereas, weed density and biomass was reduced in narrow spacing. The net income was $116 \%$ higher than sole mung bean crop and $56 \%$ higher than sole pearl millet crop in intercropped plots where the triple lines were grown both crops alternately in the strips form at $30 \mathrm{~cm}$ intra and inter strip spacing. Maximum weeds $\left(106.4 \mathrm{~m}^{-2}\right)$ were grown where single alternate lines of both crops were grown at $90 \mathrm{~cm}$ intra and inter strip distance where- as, they were minimum $\left(75.2 \mathrm{~m}^{-2}\right)$ where triple lines of both crops were grown alternately in the form of strips having $30 \mathrm{~cm}$ intra and inter strip distance. Therefore, intercropping of mung bean and pearl millet in the strips form of three lines having $30 \mathrm{~cm}$ intra and inter strip distance is recommended to the farming community of Pothwar Region of Pakistan.

\section{Novelty Statement}

Introduced the strategy to increase the net returns per unit area per unit time of the subsistence farming community of Pothwar Region of Pakistan where mono-cropping system was prevailing since centuries through efficient utilization of monsoon rains along with the management of soil health and weeds population through intercropping of pearl millet and mung-bean in summer season

\section{Author's Contribution}

Safdar Ali: Conceived the idea and supervised the research.

Muhammad Umar: Executed research and wrote article.

Bashir Ahmad Khan: Conducted economic analysis. Ijaz Ahmad: Wrote abstract and reviewed article.

Amir Manzoor: Edited article.

Muhammad Saqib Riaz: Wrote introduction and material and methods.

Muhammad Irfan Arif: Minimized similarity.

Asif Nawaz: Prepared references list.

Conflict of interest

The authors have declared no conflict of interest.

\section{References}

Achakzai, A.K.K., Habibullah, B.H.S. and Wahid, M.A. 2012. Effect of nitrogen fertilizer on the growth of mungbean [Vigna radiata (L.) Wilczek] grown in Quetta. Pak. J. Bot., 44(3): 981-987.

Agte, V., Khot, S., Girigosavi, S., Paknikar, K. and Chiplonkar, S. 1999. Comparative performance of pearl millet-and sorghum-based diets vs. wheat-and rice-based diets for trace metal bioavailability. J. Trace. Elem. Med. Biol., 13(4): 215-219. https://doi.org/10.1016/S0946672X(99)80038-8

Arunvenkatesh, S., Rajendran, K. and Baskaran, 
R. 2017. Effect of plant geometry on light interception and weed density in cotton under rainfed vertisol. Agric. Update., 12: 421425. https://doi.org/10.15740/HAS/AU/12. TECHSEAR(2)2017/421-425

Avery, D. 1997. Saving the planet with pesticides, biotechnology and European farm reform. volume 1.British Crop Protection Council"1997 Brighton crop protection conference: weeds. Proceedings of an international conference, Brighton, UK, 17-20 November 1997.Farnham (United Kingdom): British Crop Protection Council, 1997.- ISBN 0-90139645-2 (SET); ISBN 0-901396-46-0"

Brunken, J., de Wet, J.M. and Harlan, J. 1977. The morphology and domestication of pearl millet. Econ. Bot., 31(2): 163-174. https://doi. org/10.1007/BF02866587

Coutin, R. and K. Harris. 1969. The taxonomy, distribution, biology and economic importance of the millet grain midge, Geromyia penniseti (Felt), gen. n., comb. n.(Dipt., Cecidomyiidae). Bull. Entomol. Res., 59(2): 259-273. https:// doi.org/10.1017/S0007485300003199

Dhoble, M., Bhosle, B. and Khating, E. 1990. Studies on comparative performance of different intercropping systems under dryland condition. Indian J. Agron., 35(4): 346-352.

Food and Agriculture Organization of the United Nations. 2016. FAOSTAT statistical database. [Rome, Italy]

Ghilotia, Y., Meena, R. and Singh, L. 2015. Pearl millet and mung bean intercropping as influenced by various row ratios under custard apple orchard of Vindhyan region. BioScan, 10(1): 87-91.

Khan, F., Ahmed,Z.,Muhammad,A. and Hassnain, S. 2008. Response of mungbean genotypes to Rhizobium inoculum and varying levels of nitrogen fertilizer. Pak. J. Agric. Res., 21(1/4): 33-44.

Khan, M.A., Naveed, K., Ali, K., Bashir, A. and Samin, J. 2012. Impact of mungbean-maize intercropping on growth and yield of mungbean. Pak. J. Weed. Sci. Res., 18(2): 191-200.

Khattak, G.S., Ashraf, M., Elahi, T., and Abbas, G. 2003. Selection for large seed size at the seedling stage in mungbean (Vigna radiata (L.) Wilczek). Breed. Sci., 53(2): 141-143. https:// doi.org/10.1270/jsbbs.53.141

Kumar, A. and Kumar, P. 2018. Performance of advance pearl millet hybrids and mungbean under sole cropping and intercropping systems under semi arid environment. J. Pharmacogn. Phytochem., 7(2): 1671-1675.

Muthamilarasan, M., Dhaka, A., Yadav, R. and Prasad, M. 2016. Exploration of millet models for developing nutrient rich graminaceous crops. Plant. Sci., 242: 89-97. https://doi. org/10.1016/j.plantsci.2015.08.023

National Agricultural Research Centre (NARC). 2014. National coordinated maize, sorghum and millet programme. Crop sciences institute, PARC, Islamabad.

Rasul, F., Cheema, M., Sattar, A., Saleem, M. and Wahid, M. 2012. Evaluating the performance of three mungbean varieties grown under varying inter-row spacing. J. Anim. Plant. Sci., 22(4): 1030-1035.

Ram, K. and Meena, R. 2014. Evaluation of pearl millet and mungbean intercropping systems in arid region of Rajasthan (India). Bangladesh J. Bot., 43(3): 367-370. https://doi.org/10.3329/ bjb.v43i3.21616

Sharma, R., Raman, K. and Singh, A. 2009. Fodder productivity and economics of pearlmillet (Pennisetum typhoides) with legumes intercropping under various row proportions. Indian J. Agron., 54(3): 301-305.

Yadav, B., Patel, B., Ali, S. and Yadav, S. 2015. Intercropping of legumes and oil seed crop in summer pearlmillet [Pennisetum glaucum (L.) R. Br. Emend. Stuntz]. Legum. Res. An Inter. J., 38(4): 503-508. https://doi.org/10.5958/09760571.2015 .00068 .5 